\title{
Art, history, and rheumatism: the case of Erasmus of Rotterdam 1466-1536 suffering from pustulotic arthro-osteitis
}

\author{
J Dequeker
}

\begin{abstract}
Pustulotic arthro-osteitis probably associated with retroperitoneal fibrosis has been diagnosed in Erasmus of Rotterdam, based on paintings of Quentin Massys (1517) and Hans Holbein the younger (1523), historical letters of Erasmus, and postmortem examination of the skeleton.

This case report is a description of the earliest known case of pustulotic arthroosteitis, a syndrome reported for the first time in 1967 and seen more commonly in Japan than in Europe.

Works of art of many different kinds may provide an important source of evidence of disease and contribute to a better understanding of the natural history of a disease.
\end{abstract}

The pathology and history of rheumatism are still poorly understood. Insight into the pathology may be enhanced through perspectives provided by the history of disease. Visual arts, especially in combination with historical documentation of personalities, can be an important tool for palaeopathological research. ${ }^{2}$ Exploration of the antiquity of rheumatoid arthritis ${ }^{3-9}$ has been advanced by these means. Here I have studied the rheumatic features of Erasmus in paintings, letters, and postmortem reports.

Erasmus of Rotterdam (1466-1536), born 525 years ago in Rotterdam, was one of the most distinguished humanists of the Reformation period and the name of this prince of humanism is presently linked to an ambitious EuRopean Community Action Scheme for the Mobility of University Students (ERASMUS). Erasmus was the illegitimate son of a priest and a doctor's daughter. Both his parents died during his infancy and he was raised by a guardian, who eventually arranged his entry into an Augustinian order, in which he was ordained in 1492. Two years later he left monastic life to become secretary to the French bishop of Cambray and by 1499 he had begun his travels to England, France, Italy, Switzerland, and the Lowlands, which continued throughout most of his life. He was largely self taught, and as the distinction of his scholarship grew so did his acquaintance with noteworthy men of various disciplines, including the famous artists of his time.

Erasmus $^{10}$ stayed in Leuven from 1502 to 1504 and from 1517 to 1521 and enjoyed the atmosphere of the university. In a letter from Anderlecht dated 24 September 1521 to Bernard Bucho van Aytta Erasmus writes: 'At Leuven the climate is most agreeable, and there

\footnotetext{
Leuven the climate is most agreeable, and there
}

could not be a more peaceful place for study anywhere. Nowhere do the young show more enthusiasm for good literature, and many of them make wonderful progress, while the devotees of ancient ignorance protest in vain'. ${ }^{11}$ In the introduction and development of humanism in the Netherlands and its spread throughout Europe, the university of Leuven played an important part. The new movement rapidly gained ground and became strongly established in it. As early as 1517 the Collegium Trilingue was founded at the instigation of Erasmus for the study of the three biblical languages Latin, Greek, and Hebrew. Numerous famous professors taught the bonae litterae to generation after generation in the various faculties of law, medicine, etc. A large number of scholars, including Thomas More, Vesalius, Mercator, Dodoens, came to this college for further education.

Erasmus had a hard life, struggling against superstitious monks and fanatical Lutherans. In addition, he had ill health for most of his life. Despite all this he travelled through Europe on horseback, by carriage or ship and survived up to the age of 70 . As theologian, humanist, and author, he was the most famous man of his time. Erasmus's portrait has been painted by his contemporaries: the three famous painters Quentin Massys (born in Leuven), Dürer, and Holbein.

\section{Pictorial evidence of arthritis}

Figure 1 shows the half length portrait of Erasmus and detail of the hands made in 1517 by Quentin Massys (Galleria Nazionale d'Arte Antica, Palazzo Barberini, Rome) at the time Erasmus was in Leuven. The painting which is part of a diptych was intended to be given to his friend Thomas More in London. Visible are the subtle hand swellings typical for arthritis of the small hand joints. The left thumb is in hyperextension showing the characteristic $Z$ deformity secondary to chronic arthritis, and at the metacarpophalangeal joints of the index and third finger of the right hand joint synovial thickening suggestive of synovitis is discernible as well as amyotrophy of the dorsum of the hand. Just below the right eye and at the right cheek telangiectasis is suspected and at the right corner of the mouth is a small herpes-like eruption commonly found in conditions associated with fever. It is of interest to know that at the time the painting was made Erasmus was sick and was taking pills to purge 'the bile' (Letters of Erasmus, Antwerp 30 May 1917). ${ }^{12}$

Figure 2 shows the portrait of Erasmus and
Arthritis and Metabolic Unit, KU Leuven, UZ Pellenberg, B-3212 Pellenberg, Belgium $\mathrm{J}$ Dequeker 

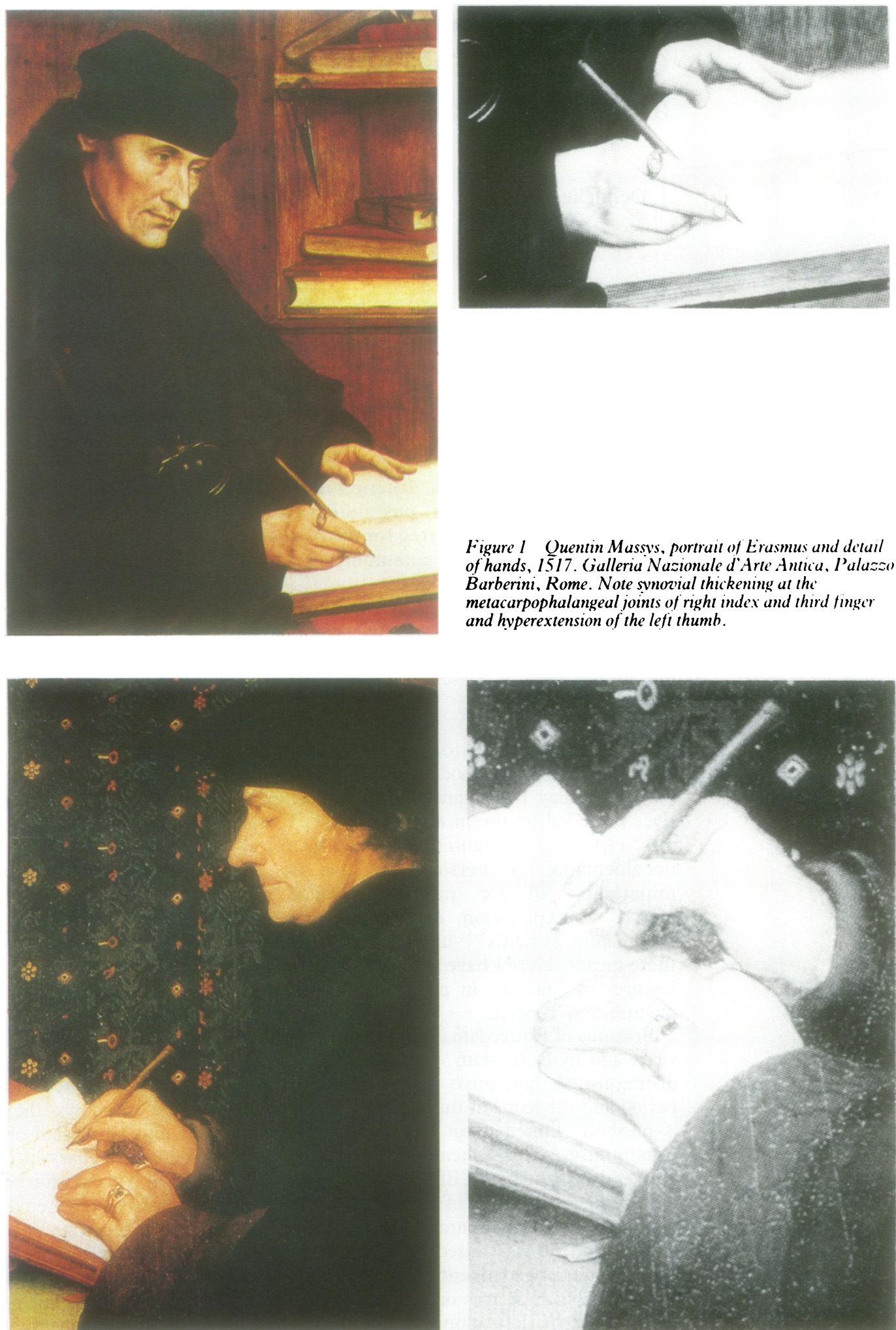

Figure 2. Hans Holbein the Younger, portrait of Erasmus, 1523. Louvre Museum, Paris. Note subluxated position of right thumb and swelling of the metacarpophalangeal joints of the left hand.

fig 3 is a study of Erasmus's hands made by Hans Holbein the Younger in 1523 (Louvre Museum, Paris) at the time Erasmus was in Basle, Switzerland. The peculiar position of the right thumb suggests a subluxation of the first metacarpophalangeal joint and the left hand, most clearly portrayed in the drawing (fig 3), shows synovial thickening at the metacarpophalangeal joints II and III and a probable swelling of the proximal interphalangeal joints.

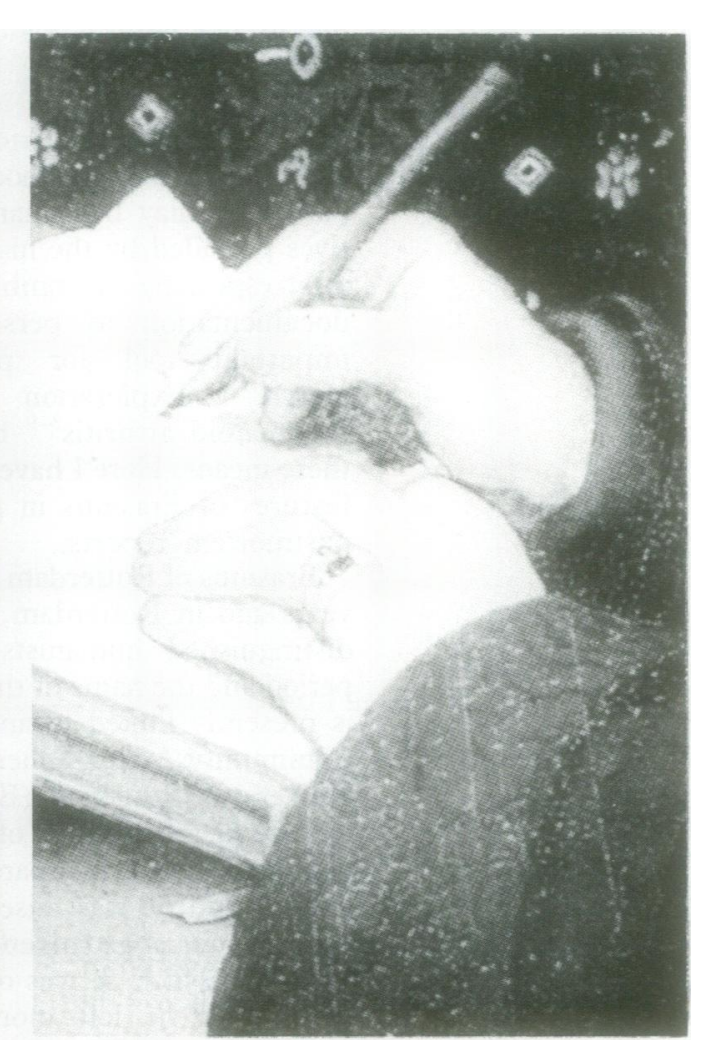

Figure 1 Ouentin Massys, portrait of Erasmus and detail of hands, 1517. (jalleria Nazionale d'Arte Antica, Palazzo Barberini, Rome. Note synovial thickening at the metacarpophalangeal joints of right index and third finger and hyperextension of the left thumb.

Albrecht Dürer also made portraits of Erasmus, of which the drawing made in Brussels in 1520 is probably the best and most realistic. The other paintings were made later in the absence of Erasmus. Erasmus was never pleased with Dürer's work. ${ }^{12}$

Figure 4, Dürer's portrait of 1520 (Collection Leon Bonnat, Louvre, Paris), shows Erasmus with his eyes cast downward. Erasmus looks much older on this drawing than on the painting 


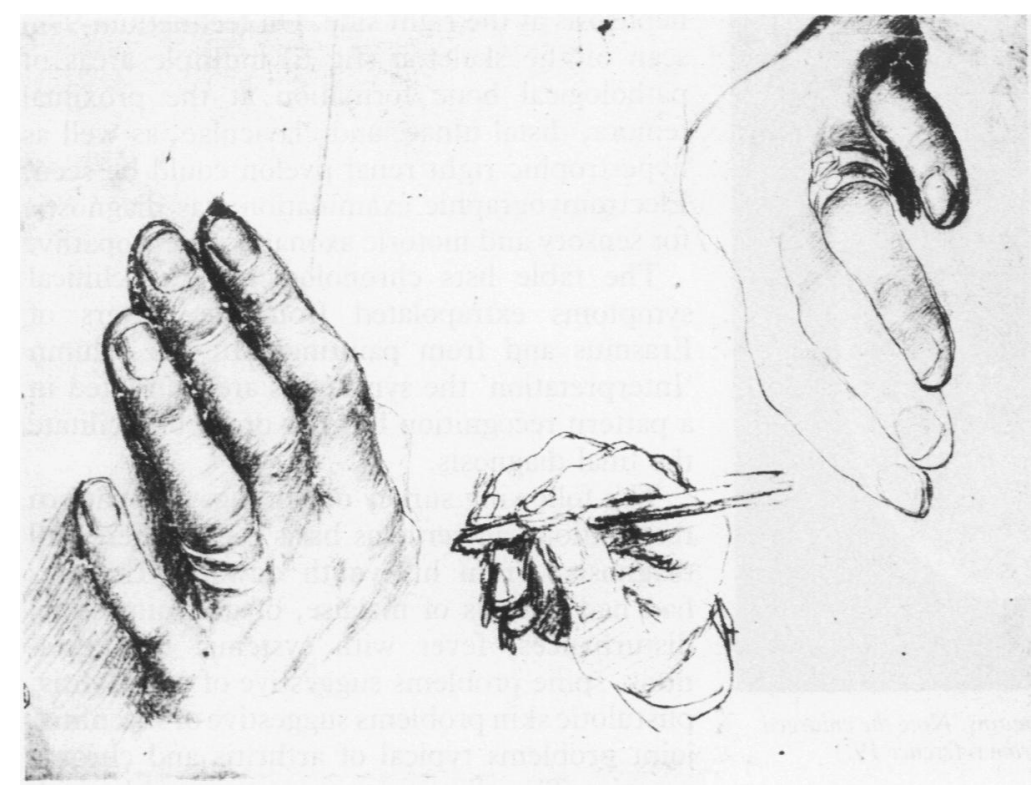

Figure 3 Hans Holbein the Younger, studies of Erasmus's hands, 1523. Drawing Louvre Cabinet des Dessins, Paris. time, especially when on a journey and when he was forced to eat fish. As he grew older he was troubled with arthritis, accompanied at times with dysentery. During a journey from Basle to Leuven (1518) a skin eruption with swelling of the nodes in the groins and with lesions under the left buttock appeared. After 17 days, black dead flesh came from the boils and a painless swelling of the left breast then developed, but reduced gradually. Because of these skin eruptions he was diagnosed as having a mild form of bubonic plague. Some think this was an unusual infection connected with syphilis.

Some doctors consider Erasmus to have been a hypochondriac and neurotic. Schenk, ${ }^{15}$ having examined his letters, concluded that Erasmus was a man of emotional volatile nature and that he was psychasthenic. Appelboom et $a l^{17}$ in their article 'The case of Desiderius Erasmus' suggest that in addition to the diagnosis of gout and syphilitic arthritis, enteric rheumatism should be considered because of his past history of dysentery and the periostitic alterations.

\section{Postmortem findings of osteitis}

The diagnosis of syphilis was reformulated when in 1928 his burial site in Basle was opened. ${ }^{19}$ The left tibia and left ulna showed some unusual changes. The left tibia was $5 \mathrm{~mm}$ shorter than the right and the left ulna $8 \mathrm{~mm}$ shorter than the right. Just below the middle of the shaft of the left tibia, on the anterior border, there was a hard, spindle-form bony proliferation $9 \mathrm{~cm}$ long. The same was true in the lower quarter of the left ulna and it was of the same type (fig 5). The bone in the affected area was thickened and porous. Studies of the decalcified bone from these areas showed on staining with haemalum that the thickening was periosteal in type. Joint destruction of the elbows, feet, and femoral head was also noted. The lumbar vertebrae as well as the pelvis were found to be intact, but no good remains of the dorsal spine and sternum were found. The sternal part of the right clavicula was missing (broken) while the sternal part of the left clavicula was normal. Werthemann did not note any alteration of the manubrium sternum. No evidence of congenital syphilis was found. The teeth were in a remarkable state of preservation. Werthemann's diagnosis was osteitis and periostitis syphilitica.

of Massys. Between 1517 and 1520 he had been suffering seriously from his rheumatism (see further).

\section{Past medical history}

Much is known and written about Erasmus's medical history of fever, pustulotic skin eruption, backache, renal stones, oligopolyarthritis, and dysentery. ${ }^{10} 13-18$ Erasmus himself wrote many letters in which he described his symptoms. As a young boy in Holland he had an attack of quartum malaria, which recurred occasionally for years. He had renal and, later, vesical calculi, which troubled him for the rest of his life. He had stomach upsets from time to

\section{Differential diagnosis}

While going through the numerous published reports of Erasmus's medical history in order to comment on the findings in the art work of Massys and Holbein, I was struck by a cluster of symptoms resembling the rare diagnosis of pustulotic arthro-osteitis which we made in a patient seen a few years ago. The patient, a 44 year old man, (ref 21 , case 4) who for many years had had intermittent pustulosis, livedo reticularis, arthritis of the hands and feet, inflammatory back pain, and lymphadenopathy, was admitted because of problems with walking, polyarthritis, and polyneuropathy.

On clinical examination, livedo reticularis, 


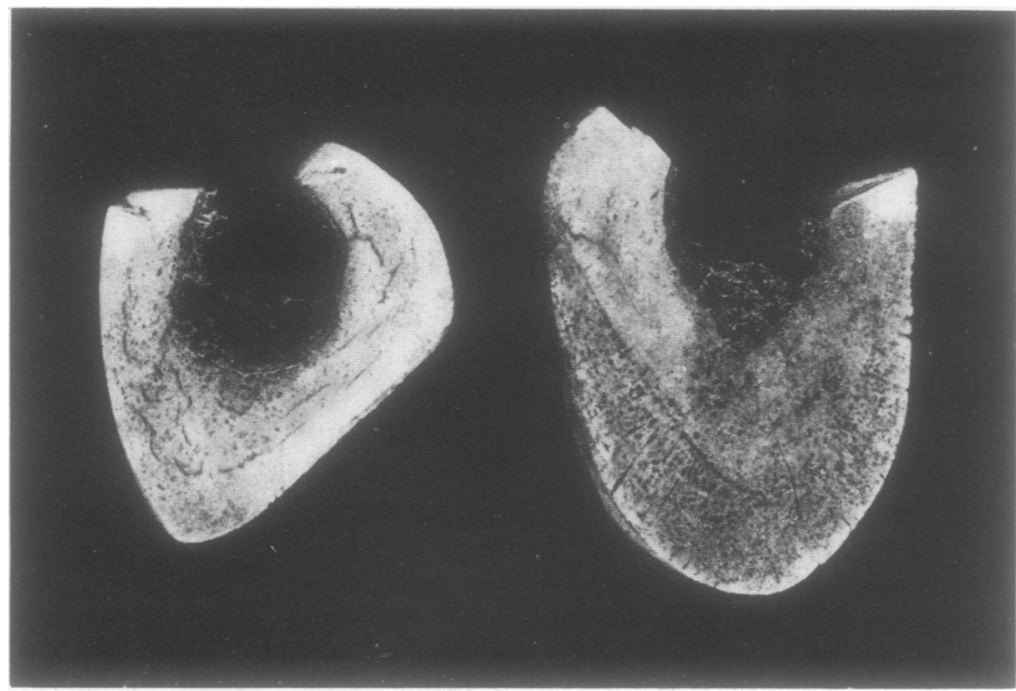

Figure 5 Cross section of the left and right tibiae of Erasmus's remains. Note the enlarged bone size on the left due to osteitis. (Reproduced with permission, from reference 19.)

sequelae of vasculitis, and scar formation on the buttocks, abdomen, and back, polyarthritis with ulnar deviation of the fingers, synovitis of the toes, knees, and elbows were noted, as well as restriction of back mobility. He had a moderately raised erythrocyte sedimentation rate-20 mm/lst h (Westergren), moderate anaemia, hypoalbuminaemia, circulating immune complexes $\mathrm{Clq}+++$, positive lupus anticoagulants, HLA-A2/A3, B7/B22, DR2, and antinuclear factor negative tests. Kidney, liver, and muscle function tests were normal and Venereal Disease Research Laboratory and HIV tests were negative. Routine $x$ ray examination showed joint narrowing of the metacarpophalangeal joints without erosions, syndesmophytes at multiple levels, unilateral sacroiliitis, hyperostosis of the claviculae and a mild pleural effusion, periosteal thickening of the proximal femur diaphysis and of the distal ulnar diaphysis. Computed tomography showed signs of constrictive pericarditis, pleural thickening, retroperitoneal fibrosis, and hydro- nephrosis at the right side. On technetium-99m scan of the skeleton (fig 6) multiple areas of pathological bone formation at the proximal femora, distal ulnae, and claviculae, as well as hypertrophic right renal pyelon could be seen. Electromyographic examination was diagnostic for sensory and motoric axonal polyneuropathy.

The table lists chronologically the clinical symptoms extrapolated from the letters of Erasmus and from paintings. In the column 'Interpretation' the symptoms are translated in a pattern recognition term in order to facilitate the final diagnosis.

The following survey of findings and pattern recognition can serve as basis for a differential diagnosis. From his youth onwards Erasmus had had periods of malaise, of gastrointestinal disturbances, fever with systemic manifestations, spine problems suggestive of spondylitis, pustulotic skin problems suggestive of vasculitis, joint problems typical of arthritis and chronic osteitis. The diagnosis most compatible with this aggregation of findings was, in 1967, described as pustulotic arthro-osteitis syndrome, also called syndrome acné pustolose hyperostose osteïte. ${ }^{20} 21$ Strongly in favour of this diagnosis is the combination of several symptoms noted in Erasmus's case-namely osteitis, arthritis, and pustulotic features. Earlier diagnoses of syphilis, osteomyelitis, plague, anglicus sudor have never been satisfactory and could not explain all his other inflammatory problems. Hyperostosis of the claviculae sternum could not be substantiated with certainty in Erasmus's case, but sternoclavicular hyperostosis - though an important finding in pustulotic arthro-osteitis-is not a necessary manifestation. ${ }^{22} 23$

Pustulotic arthro-osteitis is apparently distinct from known rheumatic diseases such as rheumatoid arthritis, ankylosing spondylitis, psoriatic arthritis, and Reiter's disease. The condition can be classified as a member of the 'seronegative spondylarthritis' group as designated by Wright and Moll. ${ }^{24}$ In addition to the diagnosis of pustulotic arthro-osteitis, I would like to suggest that Erasmus also developed retroperitoneal

Chronological summary of clinical symptoms extrapolated from letters of Erasmus

\begin{tabular}{|c|c|c|c|c|}
\hline Date & Age & City & Symptoms & Interpretation \\
\hline 1489 & 23 & Steyn monastery (Holland) & \multirow{11}{*}{$\begin{array}{l}\text { Corporis non satis recto valitudo } \\
\text { Complaints of unhealthy sleeping, poor health } \\
\text { Almost died because of fever } \\
\text { Neck pain, lymphadenopathy } \\
\text { Renal pain } \\
\text { Anglicus sudor: fever, exanthem, hidrosis } \\
\text { Lumbago } \\
\text { 'Pain in the ribs' (in costis) } \\
\text { 'pain in the kidneys' } \\
\text { Feels sick 'I am getting old' } \\
\text { Joint swelling-painting by Massys (fig 1) } \\
\text { Skin eruption, painless abscesses in groin, buttocks, } \\
\text { back, and breast, lymphadenopathy }\end{array}$} & \\
\hline 1495 & 29 & Paris Collège Montaigu & & \\
\hline 1498 & 32 & Paris & & Systemic disease \\
\hline 1506 & 40 & Bologna & & Spondylitis \\
\hline 1507 & 41 & Venice & & Spondylitis \\
\hline 1511 & 45 & Cambridge & & Systemic disease \\
\hline 1514 & 48 & Basle & & Spondylitis \\
\hline 1515 & 49 & Canterbury & & Spondylitis \\
\hline 1516 & 50 & Lowlands & & \\
\hline 1517 & 51 & Leuven & & Arthritis \\
\hline 1518 & 52 & Leuven & & Vasculitis \\
\hline 1521 & 55 & Basle & \multirow{8}{*}{$\begin{array}{l}\text { Renal bladder stones } \\
\text { Urine deposit resembled gypsum, small stones, gravel, } \\
\text { and dregs passed off with the urine } \\
\text { Joint swelling-painting by Holbein (fig 2), pain below } \\
\text { the ribs 'frigida urinam' } \\
\text { Has been working in standing position for more } \\
\text { than } 20 \text { years } \\
\text { Abscess of the adbomen, apostema duricum, changing } \\
\text { 'sweeping' skin lesions, fluid with bad odour } \\
\text { Arthritis left foot (gout) } \\
\text { Arthritis left foot, limping, right hand cannot write } \\
\text { Shoulder and arm pain, all joints painful } \\
\text { Dysentery for months, weight loss, arthritis, bedsores. } \\
\text { Postmortem examination of the skeleton: osteitis of } \\
\text { the tibia-ulna }\end{array}$} & \\
\hline 1523 & 56 & Basle & & Renal stones \\
\hline 1523 & 57 & Basle & & Arthritis \\
\hline 1526 & 59 & Basle & & Spondylitis \\
\hline 1530 & 64 & Basle & & Vasculitis \\
\hline $\begin{array}{l}1531 \\
1533\end{array}$ & $\begin{array}{l}65 \\
67\end{array}$ & Basle & & Arthritis \\
\hline 1534 & 68 & Basle & & Arthritis \\
\hline 1536 & 70 & Basle & & Osteitis \\
\hline
\end{tabular}

Figure 6 Technetium-99m bone scan of a 44 year old man with pustulotic arthroosteitis. Note the multiple areas of pathological bome formation at the proximal femora, distal ulnae, and claviculae, and hypertrophic right renal pyelon. 
fibrosis secondary to his longstanding inflammatory process. This secondary retroperitoneal fibrosis could explain the renal stone problems resulting from the obstruction of the ureters, as seen also in our clinical case described above. Retroperitoneal fibrosis was first described by Ormond in $1948 .{ }^{25}$ It is more common in men and it appears commonly in the middle decade of life. Retroperitoneal fibrosis can be associated with underlying inflammatory disorders ${ }^{26}$ but can also be secondary to methysergide and ergotamine products. The latter cause of retroperitoneal fibrosis cannot be excluded in Erasmus's case because ergotamine intoxication by infected bread was common in those days, and could also cause skin ulcerations and gangrene (St Anthony's fire), as shown in the famous altar paintings of Isenheim in Colmar (France). This condition was mainly prevalent among the poor because they could not buy good bread. In Erasmus's case history, however, ergotamine intoxication cannot explain the osteitis.

In conclusion, we think that the lifelong symptoms of multisystemic inflammation of Erasmus correspond with the diagnosis of pustulotic arthro-osteitis syndrome and that Erasmus represents the oldest reported case of this recently described syndrome. Pustulotic arthro-osteitis is thus not a recent disease as it occurred five centuries ago.

I am grateful to Professor M Sabbe and Mr G Devadder for bibliographical help, to Ms I Bigert for language correction, to Mrs J Cartois for secretarial assistance, and to Mr V Nop
Mr R Roels for excellent photographic reproduction.

1 Dequeker J. Rheumatic diseases in visual arts. General review. In: Appelboom T, ed. Art, history and antiquity of rheumatic diseases. Brussels: Elsevier, 1987: 31-40.

2 Dequeker J. Paleopathology of rheumatism in paintings. In: Ortner D J, Aufderheide A C, eds. Symposium on human paleopathology: current synthesis and future options. Washington DC: Smithsonian Institution. (In press.).

3 Dequeker J. Arthritis in Flemish paintings (1400-1700). $B M \mathcal{F} 1977$; i: $1203-5$.

4 Dequeker J, Rico H. Rheumatoid arthritis-like deformities in an early 16th century painting of the Flemish-Dutch School. $\mathcal{F A M A}$ (in press).

5 Appelboom T, De Boelpaepe C, Ehrlich G, Famaey J P. Rubens and the question of antiquity of rheumatoid arthritis. JAMA 1981; 245: 483-6.

6 Alarcon-Segovia D, Laffon A, Alcocer-Varela J. Probable depiction of juvenile arthritis by Sandro Botticelli. Arthritis Rheum 1985; 28: 600 .

7 Dequeker J. Arthritis in the paintings of Sandro Botticelli. Arthritis Rheum 1984; 27 : 1196-7.

8 Dequeker J. Polymyalgia rheumatica with temporal arteritis as painted by Jan Van Eyck in 1436. Can Med Assoc $\mathcal{F} 1981$; 124: 1597-8.

9 Dequeker J. Paget's disease in a painting by Quinten Metsys Massys). BMF 1989; 299: 1579-81.

10 Benedek T. The gout of Desiderius Erasmus and Willibald Pirckheimer: medical autobiography and its literary reflections. Bull Hist Med 1983; 57: 528-44.

11 The correspondence of Erasmus-letters 1122 to 1251,1520 to 1521. Toronto: University of Toronto Press, 1988. (Translated by Mynors RAB, annotated by Bietenholz PG.)

12 Gerlo A. In: Nieuwkoop B, De Graaf B, eds. Erasme et ses portraitistes Metsys-Dürer-Holbein. Antwerp: Mercator Fonds, 1969: 72.

13 Cole $H$ N. Erasmus and his diseases. JAMA 1952; 148: $529-31$.

14 Lindeboom G A. Erasmiana Medica. Ned Tijdschr Geneeskd 1936; 80: 3164-70.

15 Schenk V W D. Erasmus' Karakter en Ziekten. Ned Tijdschr Geneeskd 1947; 91: 702-8.

16 Nuyens B W Th. Erasmus en de Geneeskunde. Ned Tijdschr Geneeskd 1936; 91: 3157-63.

17 Appelboom T, Rouffin C, Van Herweghen J L, Vandenbrande J P, Ehrlich J. Can a diagnosis be made in retrospect? The case of. Can a diagnosis be made in 1986; 13: 1181-4.

18 Pfister C R. Zur Krankheit des Erasmus. Schweiz Med Wochenschr 1936; 35: 846.

19 Werthemann A. Schädel und Gebeine des Erasmus von Rotterdam. Basle: Verlag Emil Birkhäuser and Cie, 1930: 313-94.

20 Van Holsbeeck M, Martel W, Dequeker J, et al. Soft tissue involvement, mediastinal pseudotumor, and venous thrombosis in pustulotic arthro-osteitis. Skeletal Radiol 1989; 18: 1-8.

21 Sasaki T. A case of bilateral clavicular osteomyelitis accompanied with pustulosis palmaris and plantaris. Japanese foumal of Clinical Orthopedics 1967; 2: 333-7.

22 Huaux J P, Esselinckx W, Meunier H, Malghem J, Maldague B, Nagant de Deuxchaisnes C. Pustulotic arthroosteitis in children and adults. A report of 13 cases. Clin Exp Rheumatol 1987; 5: 143-6.

23 Gurik A G, Helmig O, Grandal H. Skeletal disease, arthroosteitis, in adult patients with pustulosis palmoplantaris. Scand I Rheumatol 1988; 70: 1-15.

24 Sonozaki H, Mitsui H, Miyanaga Y, et al. Clinical features of 53 cases with pustulotic arthro-osteitis. Ann Rheum Dis 1981; 40: 547-53.

25 Ormond J K. Bilateral ureteral obstruction due to envelopment and compression by inflammatory retroperitoneal process. F Urol 1948; 59: 1072-9.

26 Grahame I R Localized systemic sclerosis. In: Kelley W N, Harris E D Jr, Ruddy S, Sledge C B, eds. Textbook of rheumatology. Philadelphia: Saunders, 1981: 1235-52. 